\title{
Chemical equilibrium of groundwater with minerals of the host rocks in Upper Jurassic sediments (Arctic regions of Western Siberia)
}

\author{
Dmitry A. Novikov ${ }^{1, *, 2}$ \\ ${ }^{1}$ Trofimuk Institute of Petroleum Geology and Geophysics SB RAS, Laboratory of Hydrogeology of \\ sedimentary basins of Siberia, 630090 Koptuga ave. 3, Novosibirsk, Russia \\ ${ }^{2}$ Novosibirsk State University, Geological and Geophysical Department, 630090 Pirogova str. 1, \\ Novosibirsk, Russia
}

\begin{abstract}
The results of thermodynamic calculations for a water-rock system in the Upper Jurassic deposits of the Arctic regions of Western Siberia are presented. In the area under investigation the groundwaters have been identified with mineralization up to $63.3 \mathrm{~g} / \mathrm{L}$ and various chemical composition and genesis. Despite the long interaction with the rock (150-160 ma) equilibrium with endogenous minerals (albite, microcline and anorthite) is practically not observed. At the same time, groundwaters are in equilibrium with clay minerals and micas, such as: $\mathrm{Ca}-$ and Na-montmorillonites, kaolinite, paragonite, margarite, illite, muscovite and $\mathrm{Mg}$-chlorite. The establishment of a balance of groundwater with primary aluminosilicate minerals is also affected by interactions with carbonate minerals. The differences in composition of groundwater in equilibrium with certain aluminosilicates and carbonates indicate that the mineral changes are formed from a solution of a strictly defined chemical composition in an appropriate geochemical environment.
\end{abstract}

\section{Introduction}

Understanding the hydrogeochemical mechanisms of diagenesis of sedimentary rocks of oil- and gas-bearing deposits in sedimentary basins, using comprehensive studies of groundwater and host rocks, is one of the most urgent fundamental problems of modern geochemistry. The methods and approaches to the problems formulated in the present work were developed by the new theoretical concepts of Professor S.L. Shvartsev, the leader of the Siberian scientific school of thought in the field of hydrogeochemistry. These statements are largely interpreted as pioneering from the perspective of the in-depth understanding of the mechanisms of the water-rock system evolution. In the present investigation, the author has attempted to the unveil these mechanisms through the concept of a hydrogeneous-mineral complex [1].

\footnotetext{
* Corresponding author: NovikovDA@ipgg.sbras.ru
} 
The key role of water in geological processes was recognized by Academician V.I. Vernadsky, who founded hydrogeochemistry. Water as a component of minerals plays an essential part in the processes of mineral formation and transformation. Vernadsky wrote: «There is no natural body that could be compared with water in its effect on the action of majorgeological processes. There are no substances on the Earth - minerals, rocks, living organisms - that would contain no water. The matter on the Earth is permeated and encompassed by water under the action of partial forces inherent in water, its vaporized state, its omnipresence in the upper part of the planet» [2].

Irrespective of the origin and composition, waters from the very moment of their arrival into a sedimentary basin become involved in an extremely complicated sequence of geochemical processes in the 'water - rock - gas - organic matter system, which bears a clearly pronounced equilibrium-nonequilibrium nature [3].

The hydrogeochemical data underpinning the present work were obtained over a long period of time. The electronic database is fairly representative and includes the results of tests and hydrogeochemical probing of 537 objects (644 samples).

\section{Results and discussion}

Goundwaters of different compositions occur in the various geological formations in the Arctic regions of Western Siberia. The region is characterized by abnormally high formation pressures [4]. The dominant types of groundwaters are: sodium chloride, sodium chloride -bicarbonate, and sodium bicarbonate and bicarbonate-chloride (according to S.A. Shchukarev) with total mineralization varying within a broad range from 5 to $63.3 \mathrm{~g} / \mathrm{L}$ (Fig. 1) [5-16]. Each of these water types has a specific pattern of the major salt-forming major and trace component distribution; their concentrations depend directly on total mineralization (TDS). With an increase in total mineralization, the chemical type of waters changes from sodium bicarbonate - chloride to sodium chloride, while concentrations of chlorine, sodium, magnesium, calcium, potassium, and trace components - bromine, iodine, ammonium and strontium - consistently increase. At water mineralization 15-20 g/L and more, concentrations of bicarbonate ion show a decreasing trend.

The background mineralization of groundwater of the Upper Jurassic hydrogeological complex in the region under study is $19.9 \mathrm{~g} / \mathrm{L}$ (the regional background). Analysis of the zonal hydrogeochemical background revealed that groundwaters with the highest mineralization (more than $25 \mathrm{~g} / \mathrm{L}$ ) are widespread within the bounds of the Severny and Nizhnevartovsk arches, East Pur megamonocline and South Nadym megamonocline. There is a close spatial correlation between structures within the Inner tectonic area and positive hydrogeochemical anomalies with groundwaters showing increased TDS levels (above 25 $\mathrm{g} / \mathrm{L}$ ). The highest zonal hydrogeochemical background values were observed in the Severny arch structures, where the background TDS values for formation waters reach $33.5 \mathrm{~g} / \mathrm{L}$.

An increase in groundwater mineralization tends to be accompanied by a regular decrease in the values for basic genetic coefficients (i.e. genetic type ratios): for instance, the $\mathrm{rNa} / \mathrm{rCl}$ ratio values decrease from 1.2-2.1 (at TDS 5-9 $\mathrm{g} / \mathrm{L}$ ) to $0.85-0.88$ (TDS > 25 $\mathrm{g} / \mathrm{L}$. Their decrease by a factor of 2 and more is characteristic also of all other genetic coefficients: the $\mathrm{Cl} / \mathrm{Br}$ ratio values decrease from 400 (at TDS $5.1 \mathrm{~g} / \mathrm{L}$ ) to $211-275$ (at TDS more than $25 \mathrm{~g} / \mathrm{L}$ ); $\mathrm{B} / \mathrm{Br}$ changes from 3.09 to $0.07-0.17$, accordingly. Whereas the behavior of $\mathrm{rNa} /(\mathrm{rCa}+\mathrm{rMg})$ and $\mathrm{Br} / \mathrm{I}$ is found to be somewhat different from the general trends: at TDS 5-10 g/L, these ratios showed a maximal value of 50, which then progressively decreases to the previously established value of 5 for groundwaters with the highest salinity levels. 


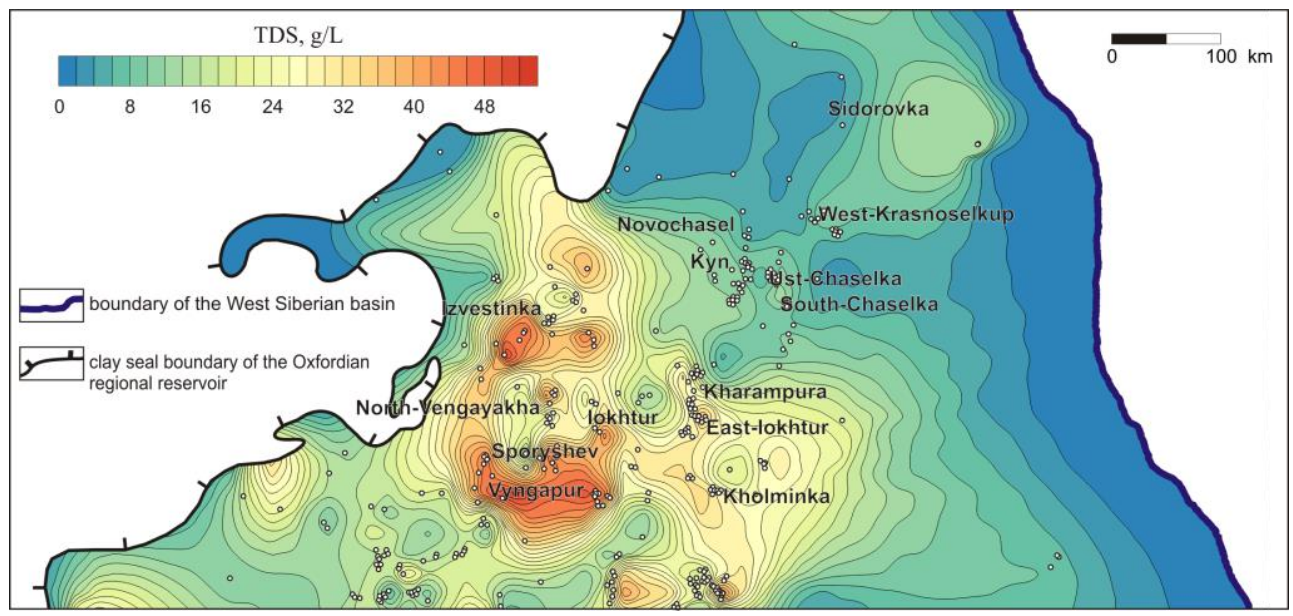

Fig. 1. The total mineralization (TDS) map of groundwaters in Oxfordian regional reservoir (Arctic regions of Western Siberia).

The $\mathrm{Br} / \mathrm{I}$ ratio has shown an increase up to 8.9 in waters with mineralization $15-20 \mathrm{~g} / \mathrm{L}$, which is followed by its decrease. The widest variation range (from 0.04 to 1.59 ) is observed for the $\mathrm{HCO}_{3} / \mathrm{Cl}$ ratio. The hydrogeochemical data analysis has revealed a decrease in the groundwaters diversity (with respect to their chemical composition) associated with an increase in TDS levels (according to S.A. Shchukarev's classification), as follows: several water types for mineralization $2-5 \mathrm{~g} / \mathrm{L}$, five types for $10-15 \mathrm{~g} / \mathrm{L}$, two types for 20-25 g/L, and only one type - sodium chloride - for mineralization more than $25 \mathrm{~g} / \mathrm{L}$.

Analysis of the points plotted on thermodynamic activity-activity diagrams of groundwater in Upper Jurassic sediments showed that these points are localized mainly in the stability fields of micaceous minerals (muscovite, paragonite, margarite) and clayey minerals (kaolinite, illite, montmorillonite). A limited number of points fit in with the stability fields of feldspar (except anorthite). The magnesium minerals stability diagrams exhibit dense, almost linear positions of points in the field of $\mathrm{Mg}$-chlorite and $\mathrm{Mg}$ montmorillonite. All the analyzed waters are saturated with respect to carbonate minerals, such as calcite and dolomite. The waters of modern seas and oceans are in equilibrium with the micaceous minerals of different compositions, which may be the result of similar geochemical evolution. In the systems $\mathrm{Si}-\mathrm{Al}-\mathrm{Na}, \mathrm{Si}-\mathrm{Al}-\mathrm{Ca}$ - with kaolinite and montmorillonites of the corresponding composition, while in the system $\mathrm{Si}-\mathrm{Al}-\mathrm{K}$ - with illite. A shift is observed for the points plotted for the composition of water from deeper horizons towards the field of feldspar (albite and microcline) in the systems $\mathrm{Si}-\mathrm{Al}-\mathrm{Na}$ and $\mathrm{Si}-\mathrm{Al}-\mathrm{K}$. This trend in the chemical evolution is also confirmed by lithological observations: the occurrence rate and amounts of newly formed albite and illite in sandsiltstone rocks of the studied sediments show an increase with depth. Whereas kaolinite, being an unstable mineral, is finally transformed (during late catagenesis and especially metagenesis) into other clayey and micaceous minerals; it is extremely rare in metamorphic rocks.

The physicochemical calculation results revealed the differences in the composition of groundwaters in equilibrium with various secondary aluminosilicate minerals and exclusively with the primary ones. It has been established that the main controlling factors of the system evolution are $\mathrm{pH}$ of the medium and concentrations of silica in the solution. Analysis of changes in $\mathrm{pH}$ and $\mathrm{H}_{4} \mathrm{SiO}_{4}$ contents in groundwaters in equilibrium with sequentially located (from clayey to endogenous aluminosilicates) minerals proves these parameters to be consistently increasing, which generally obeys the evolution scheme of the water-rock system in the zone of hypergenesis. 


\section{Conclusions}

Our results demonstrate: 1) Groundwaters developed within the Upper Jurassic sediments in Arctic regions of Western Siberia are mainly of sodium chloride, sodium chloride bicarbonate composition, varying from almost fresh to weak brines (TDS up to $63.3 \mathrm{~g} / \mathrm{L}$ ). In spite of their long-term interaction with rocks (150-160 Ma), the equilibrium with primary (endogenous) minerals - albite, anorthite, microcline - is practically not observed. At the same time, groundwaters are in equilibrium with such minerals as paragonite, margarite, illite, muscovite, $\mathrm{Ca}$ - and Na-montmorillonite, and more rarely with kaolinite and Mg-chlorite. 2) Differences in the compositions of groundwaters in equilibrium with secondary aluminosilicate minerals and, exclusively, with primary ones were established. The main controlling factors for the evolutionary development of the water-rock system are $\mathrm{pH}$ of the medium and the concentrations of silica and aluminium in solution. There also are interactions with carbonate minerals that alter the groundwater equilibrium with primary aluminosilicate minerals. 3) Differences in the compositions of groundwaters in equilibrium with specific aluminosilicates and carbonates provide evidence that new minerals are formed from a solution of strictly definite chemical composition in the corresponding geochemical environment. The amounts of silicon compounds in the formation waters critically affect the results of silicate hydrolysis. Lower concentrations of $\mathrm{H}_{4} \mathrm{SiO}_{4}$ lead to the formation of illite, while higher levels result in the formation of chlorites and in the manifestation of secondary albitization. 4) Thermodynamic analysis together with detailed investigation of groundwater geochemistry resulted in constructing a conceptual model of the sequential change of hydrogenous-mineral complexes within the bounds of Upper Jurassic sediments of the region under study. It was established that the formation of authigenic minerals occurs continuously under nonequilibrium-equilibrium conditions within the water-rock system and strictly sequentially (kaolinite montmorillonite - illite - micas - chlorite - albite - microcline), given strictly definite geochemical parameters of the medium ( $\mathrm{pH}$, concentrations of $\mathrm{SiO}_{2}, \mathrm{Al}, \mathrm{Na}, \mathrm{K}, \mathrm{Ca}, \mathrm{Mg}$ in solution) (Fig. 2). The time span plays a key role in geologic evolution of the water - rock system, and more complicated hydrogenous-mineral complexes resistant to the toughening thermobaric conditions of the catagenesis zone are formed in the course of evolution.
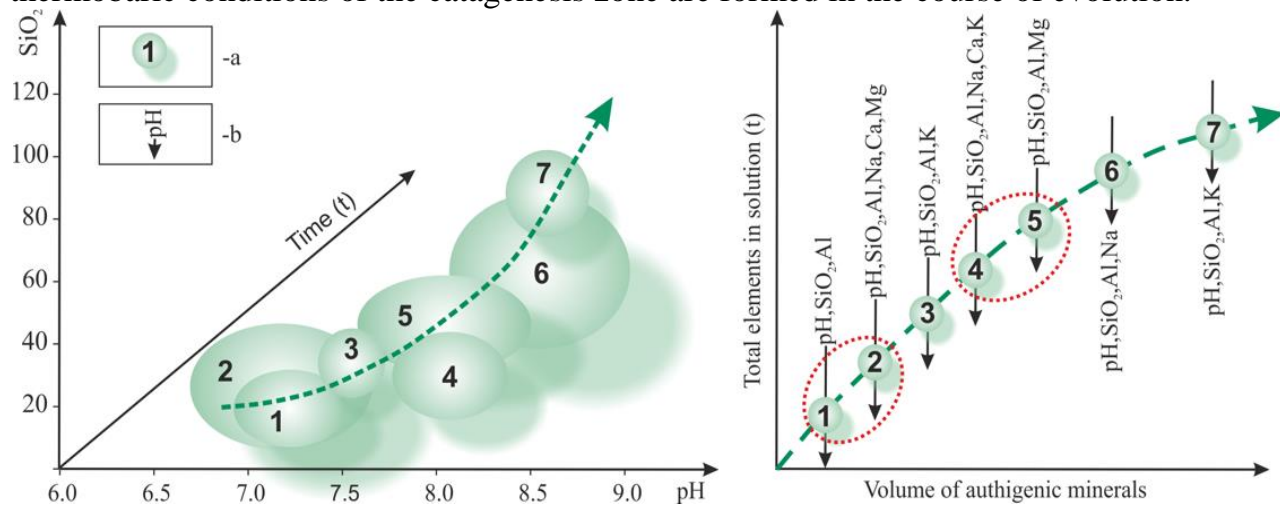

Fig. 2. The model of the successively changing hydrogenous-mineral complexes in the catagenesis zone of sediments of Arctic regions of the West Siberian artesian basin. Hydrogenous-mineral complexes: 1 - kaolinite, 2 - montmorillonite, 3 - illite, 4 - mica, 5 - chlorite, 6 - albite, 7 microcline; $b$ - geochemical controls of authigenic mineral formation.

The work was supported by the Russian Foundation for Basic Research within the scope of scientific project No 18-05-70074 «The Arctic Resources». 


\section{References}

1 S.L. Shvartsev, Lithosph., 1, 65-89 (2007)

2 V.I. Vernadsky, L.: Goskhimtekhizdat 2/1(1), 202 (1933)

3 S.L. Shvartsev, Geolog. i Geofiz., 12, 16-50 (1991)

4 D.A. Novikov, F.F. Dultsev, A.V. Chernykh, IOP Conference Series: Earth and Environmental Science, 193(1), 012050. doi:10.1088/1755-1315/193/1/012050 (2018)

5 M.B. Bukaty, D.A. Novikov, B.N. Ryzhenko, S.L. Shvartsev, 43(8), 826-829 (2005)

6 A.A. Kokh, D.A. Novikov, Wat. Res., 41(4), 396-405 (2014)

7 D.A. Novikov, A.V. Lepokurov, Geol. Neft. i Gaz. (Oil and gas Geology), 5, 24-33 (2005)

8 S.L. Shvartsev, D.A. Novikov, Geol. i geof., 45(8), 1008-1020 (2004)

9 D.A. Novikov, Petrol. Expl. and Devel., 44(5), 780-788 (2017)

10 D.A. Novikov, A.F. Sukhorukova, Arab. Jour. of Geosc., 8(10), 8703-8719 (2015)

11 D.A. Novikov, Geod. and Tecton., 8(4), 881-901 (2017)

12 D.A. Novikov, M.M. Saraev, Shiyou Kantan Yu Kaifa, Petr. Expl. and Devel., 44(5), 737-744 (2017)

13 D.A. Novikov, Neft. Khoz. - Oil Ind., 4, 16-21 (2018)

14 D.A. Novikov, IOP Conference Series: Earth and Environmental Science, 193(1), 012048, doi:10.1088/1755-1315/193/1/012048 (2018).

15 D.A. Novikov, IOP Conference Series: Earth and Environmental Science, 193(1), 012049, doi:10.1088/1755-1315/193/1/012049 (2018)

16 D.A. Novikov, Y.V. Sadykova, A.V. Chernykh, F.F. Dultsev, A.F. Sukhorukova, IOP Conference Series: Earth and Environmental Science, 193(1), 012051, doi:10.1088/1755-1315/193/1/012051 (2018) 